\title{
Decisionmaking on Multimember Courts: The Assignment Power in the Circuits
}

\author{
Daniel Hemel and Kyle Rozema*
}

May 9, 2017

\begin{abstract}
A standard assumption in the literature on judicial behavior holds that decisions of multimember courts conform to the preferences of the median judge. Judges and scholars have suggested, however, that contrary to the predictions of the median voter theorem, the judge with the power to assign the panel opinion wields disproportionate influence over case outcomes. In this article, we investigate whether the "assignment power" systematically affects outcomes on three-judge panels in the 13 federal circuits. We identify which judge presides over the panel in more than 126,000 cases across all circuits between 1993 and 2007. We exploit crosscircuit variation in the allocation of the assignment power to disentangle the effect of assignment from other attributes of presiding judges. We find that the judge who wields the assignment power is significantly less likely than other judges to dissent - an indication that assigning judges are more likely to be satisfied with the case outcome. We find evidence that assigning judges influence case outcomes through strategic assignment of opinions to other panel members, but no evidence that assigning judges influence case outcomes through strategic self-assignment of majority opinions. Our results suggest that decisionmaking on multimember courts is shaped not only by the composition of panels but also by the allocation of the assignment power among panel members.
\end{abstract}

JEL: M51

*Hemel: University of Chicago Law School, e-mail: dhemel@uchicago.edu. Rozema: Northwestern University Pritzker School of Law, e-mail: kyle.rozema@law.northwestern.edu. For helpful comments we thank Ed Fox, Jacob Goldin, Matt Spitzer, and participants at the American Law and Economics Association Annual Meeting. We thank Matt Enloe and Sean Planchard for their excellent research assistance. 


\section{INTRODUCTION}

How do multimember courts bound by majoritarian decisional rules reach the outcomes that they do? A standard assumption in the academic literature is that the judge whose preferences lie at the middle of the ideological distribution (the "median" judge) determines the ultimate result (Black, 1948). As three leading scholars of judicial behavior put it, "virtually all social scientists" agree that-at least under "certain conditions and voting procedures" - "the median can serve as an appropriate way to characterize the preferences of 'the Court' and the outcomes it reaches" (Martin, Quinn, and Epstein, 2004, p. 1278). However, judges themselves ascribe enormous influence to the judge with the power to assign the panel opinion, who is not necessarily the median judge on the ideological distribution (e.g., Fortas, 1975). In a now-public 1972 memorandum, Supreme Court Justice William O. Douglas alleged that Chief Justice Warren Burger used his assignment power "to keep control of the merits" in a highprofile case (Wahlbeck, 2006, p. 1730). ${ }^{1}$ Likewise, Harold Medina, a longtime judge on the U.S. Court of Appeals for the Second Circuit, once wrote that "the ultimate and definitive decision in a particular case" may depend "in no small measure" on how the presiding judge wields the assignment power (Medina, 1961, p. 152).

In this study, we investigate the ways in which allocation of the assignment power among panel members affects decisionmaking in the U.S. federal courts of appeals. Cases in the federal courts of appeals are decided by three-judge panels, with one of the panel members designated as the "presiding judge." The chief judge of the circuit is the presiding judge any time that she sits on a panel; otherwise, the most senior active judge on the panel presides ( 28 U.S.C. $\$ 45(b)$ ). In all but one of the circuits, the presiding judge assigns the panel opinion whenever she is in the majority. In five of the circuits, the presiding judge also assigns the panel opinion when she is in dissent. We exploit variation in the allocation of the assignment power across circuits to

\footnotetext{
${ }^{1}$ Douglas made the quoted claim in the context of Roe v. Wade, 410 U.S. 113 (1973), and leveled a similar allegation in the context of the less widely known free speech case Lloyd Corp. v. Tanner, 407 U.S. 551 (1972) (Wahlbeck 2006, pp. 1730-31).
} 
disentangle the effect of assignment power on case outcomes from other effects associated with presiding judge status.

Studying the assignment power on the federal courts of appeals can shed light on important aspects of judicial behavior for four reasons. First, the identity of the assigning judge on the federal courts of appeals is much more variable than on the Supreme Court: hundreds of judges have wielded the assignment power on different federal court of appeals panels over the past several decades, while only four individuals have served as chief justice of the U.S. Supreme Court since 1953. Moreover, the same judge may be the presiding judge on one court of appeals panel and not the next, depending on the composition of each panel and the relative seniority of its members. This institutional feature allows us to examine whether the same judge behaves differently depending on whether she has the opportunity to wield the assignment power.

Second, the judge with first claim to the assignment power on the federal courts of appeals is not always (indeed, usually not) the chief judge of the relevant circuit. In all but one of the circuits, the chief judge wields the assignment power only with respect to panels on which she sits. As a result, the federal court of appeals setting allows us to disentangle the effect of the assignment power from the effect of the chief judge. By contrast, in the Supreme Court setting, there is likely no credible way to separate the influence that the chief justice exerts by virtue of being the leader of the institution from the influence that the chief justice wields through the assignment power.

Third, the federal courts of appeals are a worthy subject of study in their own right because of the extraordinary impact they have on the development of American law. The federal courts of appeals resolve thousands of cases each year, whereas in recent years the U.S. Supreme Court has issued fewer than 100 merits opinions per term. Oftentimes it is a federal court of appeals, not the Supreme Court, that speaks the 
last word on a case of national significance. ${ }^{2}$ Understanding how these courts arrive at the outcomes they do is an important question even if the findings are not generalizable to the Supreme Court.

Finally, and perhaps most importantly, variation across circuits in the allocation of the assignment power allows us to explore whether and how institutional rules and practices shape the decisions reached by majoritarian bodies. We employ a novel strategy for determining whether subtle differences in decisional norms across multimember bodies concretely affect the outcomes those bodies reach. While our study focuses on the U.S. federal court of appeals setting, our findings are potentially generalizable to other multimember courts as well as non-judicial committees that express their conclusions through reasoned single-author opinions (e.g., multimember administrative agencies such as the Federal Communications Commission and the Securities and Exchange Commission).

To study the assignment power, we compiled data on the outcome of every federal court of appeals case in which an opinion was issued from 1993 to 2007. We matched these data to information on judges, including their status as chief, active, and senior in each month. For each case, we determined the members of the panel, which member was the presiding judge, how each member voted, and which member wrote the majority opinion. ${ }^{3}$

We first consider whether the status of presiding judge increases the likelihood that a panel member will achieve an outcome that is satisfactory from her own perspective. We use a revealed preference measure of outcome satisfaction: whether the

\footnotetext{
2 For recent examples of particular prominence, see Texas v. United States, 809 F.3d 134 (5th Cir. 2015), affirmed by an equally divided Court, 136 S. Ct. 2271 (2016), in which the Fifth Circuit struck down Obama administration executive actions regarding undocumented immigrants; and Washington v. Trump, 847 F.3d 1151 (9th Cir. 2017), in which the Ninth Circuit upheld an order blocking implementation of the Trump Administration's ban on entry from seven predominantly Muslim countries.

${ }^{3}$ Not every opinion has an identifiable author: $20 \%$ of cases in our sample result in "per curiam" opinions (i.e., opinions issued in the name of the court rather than a particular judge). We include per curiam opinions in our analysis and discuss their implications below.
} 
judge dissents from the majority. ${ }^{4}$ We find that presiding judges are less likely than other judges on the panel to dissent, which suggests that the presiding judge is indeed more likely to achieve what she considers to be a satisfactory outcome. This finding remains robust to the inclusion of control variables for chief judge status and relative experience of panel members.

We next exploit variation across circuits in the allocation of the assignment power to disentangle the effect of assignment from other effects attributable to presiding judge status. We find strong evidence that the assignment power decreases the likelihood that a presiding judge dissents. In particular, the probability that the presiding judge will dissent is lower in circuits in which the presiding judge wields the assignment power than in the one circuit that allocates the assignment power differently. We also compare circuits in which presiding judges hold a stronger form of the assignment power (ability to assign the panel opinion in every case) to circuits in which the assignment power is weaker (ability to assign the panel opinion only when the presiding judge is in the majority). We find that presiding judges who enjoy a stronger form of the assignment power are less likely to dissent.

Finally, we consider pathways through which presiding judges may exert influence over case outcomes via the assignment power. One possibility is that presiding judges with power over opinion assignment shape outcomes by assigning opinions to themselves, which allows them to assert agenda control through the opinion draft. Another possibility is that presiding judges who wield the assignment power strategically assign opinions to co-panelists. We find no indication of strategic selfassignment, but we do find evidence suggesting that presiding judges with power over opinion assignment influence case outcomes through strategic assignment of opinions to other panel members. Specifically, we find that presiding judges with the assignment power are less likely than other judges to dissent from panel opinions when not the

\footnotetext{
${ }^{4}$ In the Appendix, we also report results using a broader definition of disagreement: whether the judge dissents or writes separately from the majority in a concurring opinion. Our substantive results are consistent across both definitions of disagreement.
} 
majority opinion author. In other words, presiding judges with the assignment power appear to be more satisfied with the panel opinions written by others.

This article builds on a literature that studies the influence of opinion assignment on judicial outcomes in the context of the U.S. Supreme Court (e.g., Ulmer, 1970; Slotnick, 1979; Brenner and Spaeth, 1986; Maltzman and Wahlbeck, 1996; Wahlbeck, 2006; Bonneau et al., 2007; Lax and Cameron, 2007). The one empirical study that examines patterns of opinion assignment in the federal courts of appeals focuses specifically on the outcomes of sexual harassment cases (Farhang et al., 2015). We are, to our knowledge, the first to exploit differences across circuits in rules for allocating the assignment power, and the first to investigate the effect of the assignment power on case outcomes at the court of appeals level across a full range of issue areas.

The article is organized as follows. Section 2 discusses ways in which allocation of the assignment power among panel members might affect case outcomes. Section 3 describes the data. Section 4 reports the results of our empirical analysis. Section 5 discusses the implications of our results and concludes.

\section{BACKGROUND AND THEORY}

This section focuses on ways in which the allocation of the assignment power among panel members may affect case outcomes. We begin by providing details regarding the institutional setting of the federal courts of appeals. We next discuss preferences and incentives of judges regarding opinion assignments, and we identify ways in which judges may influence case outcomes through opinion assignments. Finally, we articulate testable hypotheses that will allow us to distinguish among different causal mechanisms.

Institutional Setting. Cases on the federal courts of appeals are initially heard in panels of three judges. ${ }^{5}$ In all circuits, one panel member is designated as the presiding

\footnotetext{
${ }^{5}$ In very rare instances, a high-profile case will be heard by the full court en banc before an initial panel has rendered a decision. See, for example, West Virginia v. U.S. Environmental Protection Agency, No. 15-
} 
judge, and that judge leads a discussion among panel members at a "conference" following oral argument. Panel members cast preliminary votes on cases at the conference (Bowie, Songer, and Szmer, 2014, p. 63; Cohen, 2002, p. 136).

In all but one circuit, the presiding judge assigns the panel opinion whenever the presiding judge is in the majority (Cheng, 2008, p. 527 n. 35; Nash, 2014, p. 1625 n. 86). The one exception is the Fourth Circuit: according to that court's internal operating procedures, "[o]pinion assignments are made by the Chief Judge on the basis of recommendations from the presiding judge of each panel on which the Chief Judge did not sit." The chief judge "consult[s] with the presiding judge of each panel" regarding opinion assignments, but the chief judge assigns the opinion herself "with the objective of as even a distribution of the workload as can be achieved."6

The circuits also differ in how they allocate the assignment power when the presiding judge is in dissent. In the Fifth, Sixth, ${ }^{7}$ Seventh, Eighth, and Ninth Circuits, the presiding judge enjoys an especially strong form of the assignment power: she assigns the panel opinion regardless of whether she is in the majority or in dissent. In the First, Second, Third, Tenth, Eleventh, D.C., and Federal Circuits, the presiding judge assigns the panel opinion only when she is in the majority. In other cases, the next

1363 (D.C. Cir.) (en banc) (oral argument held Sept. 27, 2016), in which the D.C. Circuit considered challenges to the Obama administration's Clean Power Plan; and International Refugee Assistance v. Trump, No. 17-1351 (4th Cir.) (en banc) (oral argument held May 9, 2017), in which the Fourth Circuit considered challenges to the Trump administration's second executive order barring entry from six predominantly Muslim countries. As explained below, we exclude en banc cases from our analysis.

${ }^{6}$ U.S. Court of Appeals for the Fourth Circuit, Local Rules of the Fourth Circuit; Internal Operating Procedures, I.O.P. 36.1, at 32 (Dec. 1, 2016), http://www.ca4.uscourts.gov/docs/rules/LocalRules.pdf. One author reports that "anecdotally, the prerogative of the chief judge is rarely if ever exercised" (Cheng, 2008, p. 530, n. 53). However, the fact that the chief judge ultimately must approve opinion assignments may affect the extent to which presiding judges incorporate strategic considerations into their assignment recommendations. As discussed below, we do indeed find evidence suggesting that presiding judges there behave differently than presiding judges in other circuits who enjoy plenary power over opinion assignments.

7 Sources differ in their description of the Sixth Circuit's opinion assignment practices (Bowie, Songer, and Szmer, 2014, p. 67; Hettinger, Lindquist, and Martinek, 2003, p. 91). We have confirmed on the basis of Sixth Circuit's internal operating procedures as well as interviews with former clerks that opinions are assigned by the presiding judge on each panel. U.S. Court of Appeals for the Sixth Circuit, Federal Rules of Appellate Procedure; Sixth Circuit Rules; Sixth Circuit Internal Operating Procedures; Sixth Circuit Guide to Electronic Filing, 6 Cir. I.O.P. 32.1(a)(1), at 86 (Dec. 1, 2016), http:/ / bit.ly/2pwYvef. 
highest-ranking judge in the majority assigns the panel opinion (Cheng, 2008, p. $527 \mathrm{n}$. 35).

Incentives Regarding Opinion Assignment. While the norm is for panel members to divide up opinions roughly equally (Bowie, Songer, and Szmer, 2014, p. 68), the number of opinions per panel is not always divisible by three, and so an assigning judge will sometimes have an opportunity to allocate an additional opinion to herself or to another panel member. In making that decision, the assigning judge faces a tradeoff. On the one hand, opinion writing is a potentially time-consuming task, and an assigning judge with a taste for leisure may have an incentive to assign the extra opinion to another panel member. On the other hand, writing the first draft of the panel opinion may present an opportunity for agenda control. The assigned author generally sends her first draft to co-panelists before any competing opinions are circulated, giving her an opportunity to structure the panel's choice among policy alternatives and to direct attention toward a particular alternative. The norm that the assigned author circulates her draft first also may allow her to obtain early commitments from copanelists to join her opinion before a dissent has circulated (Wahlbeck, 2006, p. 1734).

Even beyond the opportunities for agenda control, judges may find some writing assignments to be more congenial than others (Cheng, 2008, p. 543). For example, a judge who was an antitrust lawyer earlier in her career may have a preference for writing in antitrust cases. Likewise, a writing assignment in a high-profile or precedentsetting case may be attractive to a judge who desires public attention or subsequent citations. Conversely, a writing assignment in a record-intensive, fact-bound case may be undesirable because drafting the opinion is a laborious endeavor with little reputational payoff.

Given the opportunity for agenda control that comes with writing the panel opinion, assigning judges may have an incentive to assign opinions in controversial cases to themselves. In some instances, however, the assigning judge may choose to assign the opinion in a controversial case to an ideologically sympathetic co-panelist 
instead. This may be because the assigning judge already has chosen to self-assign the opinion in a different case, and self-assigning the opinion in a second case would result in a workload imbalance among panel members. Or it may be because the opinion in the controversial case is particularly costly to write (e.g., it involves an unusually lengthy record), and so the assigning judge prefers to allow another panel member to draft the opinion even though that entails some loss of agenda control.

A judge who wields the assignment power also may exert influence over copanelists by using desirable and undesirable writing assignments as bargaining chips. She may be able to use her power over assignments to procure substantive concessions from other panel members regarding case outcomes. Even if such bargaining is not explicit, the assigning judge's ability to structure the workload of her co-panelists may make others more deferential to the assigning judge's preferences so that they receive more desirable assignments.

So far, we have suggested that allocation of the assignment power may affect case outcomes (a) because assigning judges strategically self-assign majority opinions in controversial cases and (b) because assigning judges strategically assign majority opinions to other panel members. A third way in which allocation of the assignment power may affect judges' votes is specific to circuits in which the presiding judge can assign the majority opinion only when she herself is a member of the majority. In such circuits, the presiding judge may be more reluctant to dissent because she does not want to cede control over opinion assignment.

Presiding judges also may sway case outcomes for reasons unrelated to the assignment power. First, the presiding judge is only presiding because she is (a) the chief judge or (b) the longest-serving judge on the panel in active status - both of which may be sources of influence independent of presiding judge status. Second, the presiding judge may wield influence over case outcomes through mechanisms other than self-assignment. As noted above, the presiding judge generally leads the discussion among panel members at conference, and the judge who leads the postargument discussion may enjoy an agenda-setting power distinct from the power 
associated with opinion assignment (Cross and Lundquist, 2006, p. 1668). As explained below, cross-circuit differences in the allocation of the assignment power will allow us to distinguish the effect of assignment from other effects of presiding judge status.

Hypotheses. Our informal analysis above suggests that a judge with the opportunity to assign the panel opinion may influence case outcomes through strategic self-assignment of opinions in controversial cases as well as strategic assignment of opinions to other panel members. If the judge with the assignment power influences case outcomes through either of these mechanisms, we expect that the assigning judge is more likely to be satisfied with the panel opinion-and, for that reason, less likely to dissent. This line of logic supports a first working hypothesis:

\section{H1: A judge with the opportunity to assign the panel opinion is less likely to dissent than other judges on the panel. ${ }^{8}$}

We also investigate the mechanisms through which judges wielding the assignment power exert influence over case outcomes. If the effect of the assignment power operates exclusively through strategic self-assignment, we would not expect a difference in dissent rates between judges with the strong form of the assignment power (i.e., the ability to assign the panel opinion whether in majority or in dissent) and judges with a weaker form of the assignment power (i.e., the ability to assign the panel opinion only when in dissent). With either the strong form or the weak form of the assignment power, the presiding judge has the option to self-assign when in the majority. If the effect of the assignment power operates through strategic assignment of panel opinions to ideologically sympathetic co-panelists, however, then we might indeed expect to see a lower dissent rate among presiding judges in strong-form circuits

\footnotetext{
8 We use the phrase "opportunity to assign the majority opinion" to refer to presiding judges in strongform and weak-form circuits. In either type of circuit, the presiding judge has an opportunity to assign the panel opinion even though-in weak-form circuits - she may sacrifice that opportunity by initially voting to dissent.
} 
than in weak-form circuits. This is so because in a strong-form circuit, a presiding judge who is in the dissent on the initial vote still has control over opinion assignment, and thus can assign the panel opinion to the judge in the majority whose views are closest to her own. The more ideologically sympathetic co-panelist is then more likely to write a middle-ground opinion that ultimately leads the presiding judge to join. In a weak-form circuit, a presiding judge who initially indicates an intention to dissent thereby loses control over opinion assignment in that case. The assignment may then go to the more extreme co-panelist, who is less likely to write a middle-ground opinion that regains the support of the presiding judge. Likewise, if the effect of the assignment power is explained by assigning judges using opinion assignments as bargaining chips, then we might expect to see a lower dissent rate among presiding judges in strong-form circuits. This is so because a presiding judge in a strong-form circuit has control over more opinion assignments, and thus has more bargaining chips at her disposal.

This logic leads to a second working hypothesis:

H2: A judge with a strong form of the assignment power (i.e., power to assign the panel opinion whether in majority or in dissent) is less likely to dissent than a judge with a weak form of the assignment power (i.e., power to assign the panel opinion only when in the majority).

If judges with the assignment power influence case outcomes through strategic self-assignment, then we might expect self-assignment to be more likely in some circumstances than in others. When a judge assigns an opinion to herself, she potentially gains greater control over the case outcome, but with the cost of having to write an opinion. If the assigning judge is in full accord with fellow panel members, she may have little incentive to bear the cost of writing an additional opinion; instead, she can assign the opinion to an ideologically sympathetic co-panelist and save herself the opinion writing costs. If the assigning judge's views differ from other panel members, however, she may have a stronger incentive to assign the opinion to herself-and thus 
to exert more control over the outcome. The assigning judge's views are most likely to diverge from those of other panel members when the assigning judge is in the ideological minority. Thus, insofar as judges with the assignment power exert influence over case outcomes through strategic self-assignment, we might expect judges in the ideological minority to be more likely to self-assign. This rationale leads to a third working hypothesis:

H3: The effect of the assignment power on the probability of authoring the panel opinion is greater for a judge in the ideological minority than for a judge in the ideological majority.

An alternative way to determine whether assigning judges exert influence over case outcomes through strategic self-assignment or strategic assignment of opinions to co-panelists is to look at votes of non-authoring judges. If the only mechanism through which the assigning judge influences case outcomes is through self-assigning the majority opinion in controversial cases, then we would not expect to see an effect of the assignment power in cases in which that judge is not the author of the majority opinion. If, however, assigning judges influence case outcomes through strategic assignment of panel opinions to co-panelists, then we might expect judges with the assignment power to join their co-panelists' opinions at a higher rate than judges without the assignment power join their co-panelists. We also might expect that effect to be stronger among judges with a strong form of the assignment power than judges with a weak form, because judges with a strong form of the assignment power have a greater opportunity to influence outcomes through assignment of opinions to co-panelists. These rationales lead us to two final working hypotheses:

H4: A judge with the opportunity to assign the panel opinion is less likely to dissent in cases in which she is not the author of the majority opinion than a 
non-assigning judge is in cases in which she is not the author of the majority opinion.

H5: A judge with a strong form of the assignment power is less likely to dissent in cases in which she is not the author of the majority opinion than a judge with a weak form of the assignment power is in cases in which she is not the author of the majority opinion.

\section{DATA AND DEscriptive STATISTICS}

In this section, we describe our dataset and present descriptive statistics. Our dataset identifies the judges on each court of appeals case, the judge who wrote the majority opinion, the judges who dissented or wrote separately on each case, and the judge who presided over each case. The determination of which judge presided in a case requires information on the status of each judge on each case (i.e., chief judge, active judge other than the chief judge, or senior judge), and the relative seniority of the judges on each panel. We match information from three sources. First is data on the status of each court of appeals judge in each calendar month from 1993 to 2007 (chief, active, and senior). Second is data on each federal court of appeals case from 1993 to 2007. Third is supplemental data on judges, including the political party of their appointing president.

\section{A. Data on Court of Appeals Judges}

We have created a dataset that we use to identify which judge presided over each court of appeals case. The judge who presides is determined as follows. First, if the chief judge is on the panel, that judge presides. Second, if no chief judge is present, the active judge on the circuit with longest time of service presides. We began with data on judge appointment date, retirement date, and termination date from the Biographical Directory of Federal Judges, maintained by the Federal Judicial Center. The directory 
does not include information on the date that a judge became or ceased to serve as chief judge, so we hand-collected data on chief judges from alternative sources. ${ }^{9}$

From this information, we first establish a panel that identifies the status of each court of appeals judge as chief, active, or senior in each calendar month. From these data, we establish who the presiding judge would be for the complete set of three-judge panels convened within a circuit in each calendar month.

\section{B. Court of Appeals Opinions}

To create a dataset on panel composition and case outcomes, we obtained text files of every court of appeals opinion published in the Federal Reporter, Third Series (F.3d) from 1993 to $2007 .{ }^{10}$ It is worth emphasizing that the cases contained in F.3d are cases that make precedent for the circuit. Non-precedential decisions are generally excluded from F.3d. Thus, although the federal courts of appeals usually resolve more than 30,000 cases on the merits each year (Administrative Office of the U.S. Courts, 2016), opinions published in F.3d account for a fraction of all cases heard (less than onefifth of the total in some of the years that our study covers).

Each case file contains the entire court opinion. The files typically follow a standard format, which allows us to parse the opinions and extract the following information for cases: (1) the judges on the case, (2) the judge who wrote the panel opinion, (3) any judge who dissented, (4) the date that the opinion was handed down, and (5) the circuit in which the case was heard. Most cases are heard by a panel entirely composed of judges from that circuit. Occasionally, however, federal judges from other courts (district judges, court of appeals judges from other circuits, and senior associate justices of the Supreme Court) hear cases on a circuit court by designation. Under 28

\footnotetext{
${ }^{9}$ Wikipedia has compiled remarkably detailed data on the tenure of chief judges, which we cross-checked against chief judge identifiers in the Federal Reporter series. The rules for which judge serves as chief judge are set forth in 28 U.S.C. $\S 45$. When the chief judgeship becomes vacant, a successor is chosen from among the active judges of the circuit according to the following rule: the longest serving active judge under age 65 who has served for at least one year and never previously served as chief judge becomes the new chief. The new chief then serves for seven years or until reaching age 70, whichever comes sooner. ${ }^{10}$ We obtained HTML files through a website maintained by the nonprofit Public.Resource.Org.
} 
U.S.C. $\S 45(b)$, a judge of another court cannot serve as presiding judge. ${ }^{11}$ We retain only the votes of judges who were appointed to the circuit in which the case was heard. We do so because a judge from another court sitting by designation faces a situation very different from that of a home court judge. Other scholars have found that judges sitting by designation exhibit distinctive voting patterns (Green and Atkins, 1978; Haire, Lindquist, and Songer, 2003). We also exclude en banc cases. These cases are heard in panels larger than three judges that almost always include the chief judge, who presides over the en banc court. En banc decisionmaking entails a set of strategic considerations independent of those that apply in the panel setting (e.g., Giles, Walker, and Zorn, 2006).

This leaves us with 126,224 cases, $3.1 \%$ of which had a dissenting opinion. We reshape the data to the vote level for judges who were appointed to the circuit, which leaves us with 346,463 home judge votes. Given that we exclude non-home court judges, there are an average of 2.7 judges per case. The percent of dissents at the vote level is $1.1 \%$ (3.1\%/2.7 judges per case).

An alternative approach to defining disagreement among judges would be to include both dissent and concurrence as an indication of disagreement. In some cases, a judge may disagree with the panel's reasoning but concur because a separate line of reasoning leads her to the same ultimate disposition. Whether or not she reaches the same bottom line result (e.g., "affirm," "remand," "vacate") can be less significant than the reasoning she applies. (Concurrences of this variety are often, but not always, labeled as "concurrences in part" or "concurrences in the judgment.") In other circumstances, a judge may agree with the panel's reasoning in full but may write a separate concurrence to raise a point not addressed by the majority (e.g., to suggest that

\footnotetext{
11 The one exception to this rule is that the sitting Supreme Court justice who serves as circuit justice for a particular circuit will preside over any panel of which she is a member. 28 U.S.C. $\S 45(\mathrm{~b})$. This is an extremely rare occurrence: the most recent instance was in 2005, and resulted from the fact that Chief Justice John Roberts already had been a member of the panel before he was elevated from the D.C. Circuit to the Supreme Court. Banner v. United States, 428 F.3d 303 (D.C. Cir. 2005). Before that, the last instance was in 1992, and similarly involved the elevation of an original panel member (Clarence Thomas) from the D.C. Circuit to the Supreme Court while the case was pending. Center for Auto Safety v. Federal Highway Administration, 956 F.2d 309 (D.C. Cir. 1992).
} 
a relevant precedent should be overturned or to draw attention to an argument that the parties failed to fully brief). We focus on dissenting opinions as a more conservative measure of disagreement. As a robustness check, we repeat our analyses including both dissent and concurrence as our outcome measure for disagreement. All of our substantive results are consistent across the two specifications. We report results using the alternative outcome measure in an Appendix.

\section{Descriptive Statistics}

Figure 1 plots the number of cases and votes over time. The caseload in circuit courts spiked during the mid-1990s to around 15,000 cases per year, and remained fairly constant at 6,000 cases per year during the 2000s. The number of votes is roughly three times the number of cases, reflecting the fact that most panels have three home court judges. The year-to-year changes in votes closely tracks the changes in cases, which suggests that the share of home court judges on cases is fairly constant over time.

\section{Insert Figure 1 about here}

Figure 2 plots the dissent rate over time. During the mid-1990s, the dissent rate was relatively constant at around $0.9 \%$. The rate increased to around $1.5 \%$ the late $1990 \mathrm{~s}$ and remained relatively constant thereafter. Viewed in light of Figure 1, which showed a decrease in caseload in the late 1990s, the increase in the dissent rate could reflect the fact that judges tend to write a relatively flat absolute number of dissenting opinions each year. Thus, when the number of cases decreases, we might expect the rate of dissent to increase (as we observe).

\section{Insert Figure 2 about here}

Table 1 provides descriptive statistics by circuit. Each column reports annual averages by circuit. The average number of home judges who heard at least one case in 
a year varies considerably between circuits, from as high as an average of 42 judges on the Ninth Circuit to as low as 10 judges on the First Circuit. Note that this includes both active and senior judges. The number of cases heard also varies considerably across circuits, and as expected is typically higher for circuits with more judges. The number of average votes in a given year is less than 3 times the number of cases, which is a result of the majority of panels being three home judges but some panels including one or two judges sitting by designation. To reiterate, even though the panel minimum is three judges, we observe fewer than three judge votes on a case because we retain only votes of home judges. The dissent rate ranges from as high as an average of $3.0 \%$ on the Third Circuit to as low as $0.3 \%$ on the First Circuit.

\section{Insert Table 1 about here}

To assess whether judges systematically differ in their propensity to dissent, Figure 3 plots the distribution of the dissent rate at the judge level. We observe that the median dissent rate is $1.5 \%$, but a sizable fraction of judges dissent at rates above $2 \%$ and even $3 \%$. The dissent rate differs by presiding status, with presiding judges dissenting at a rate of $1.0 \%$ compared to $1.2 \%$ for non-presiding judges. In the next section, we explain how we identify the effect of the assignment power on dissent.

\section{Insert Figure 3 about here}

\section{EMPIRICAL APPROACH AND RESUlts}

\section{A. Identification}

Equation (1) sets out our main econometric specification. 


$$
d_{i c t}=\alpha+\beta A_{i c t}+\theta S_{i c t}+\eta P_{i c t}+\gamma I_{i c t}+\zeta E_{i t}+\psi C_{i t}+\kappa M_{i c}+\phi_{i}+\sigma_{t}+\varepsilon_{i c t}
$$

where $d_{i c t}$ is an indicator for whether judge $i$ dissented in case $c$ in year $t$. As described below, $P$ is an indicator for presiding status, $A$ is an indicator for the assignment power, $S$ is an indicator for a strong form of the assignment power, $I$ is an indicator for a judge in an ideological minority on the panel, $E$ is the experience of the judge, $C$ is an indicator for the chief judge, and $M$ is an indicator for the most experienced judge on a panel. In the baseline model, we control for year fixed effects $\sigma_{t}$. We enrich the model with judge fixed effects $\phi_{i}$, which nets out idiosyncratic differences in the propensity for judges to dissent.

We briefly discuss the construction of each of our independent variables:

Presiding Judge Status $(\boldsymbol{P})$. As prescribed by circuit rules, a judge is the presiding judge on the panel if she is the chief judge or, if the chief judge is not on the panel, if she is the longest-serving judge on the panel in active status.

Assignment Power $(A)$. A judge holds assignment power if she has authority to assign the panel opinion whenever she is in the majority. In all circuits other than the Fourth Circuit, the presiding judge holds assignment power. In the Fourth Circuit, the presiding judge holds assignment power only if she is the chief judge; otherwise, no judge on the panel holds assignment power.

Strong Form of Assignment Power (S). A judge holds a strong form of the assignment power if she has authority to assign the panel opinion regardless of whether she is in the majority or she dissents. As noted above, presiding judges in the Fifth, Sixth, Seventh, Eighth, and Ninth Circuits hold the assignment power in strong form $(P=1 ; A=1 ; S=1)$. In the First, Second, Third, Tenth, Eleventh, D.C., and Federal Circuits, the presiding judge holds assignment power but not the strong form of the assignment power $(P=1 ; A=1 ; S=0)$. 
Ideological Minority (I). Using the party of the appointing president as a proxy for ideology, we control for whether a judge is in an ideological minority on the panel. To do so, we define judge $i$ on case $c$ as a minority judge $I$ if she was appointed by a Democratic president and the other panel members were appointed by a Republican president, or vice versa.

Experience $(E)$. We control for the possibility that the propensity to dissent varies over a judge's length of service by including a variable $E$, which measures the number of months the judge has been on the court. Experience may affect a judge's propensity to dissent in a number of ways. First, knowledge of doctrine or understanding of interpersonal dynamics that comes with experience may allow a judge to exert influence over case outcomes in subtle ways. Second, with experience may come self-confidence, and more self-confident judges may be more willing to dissent from their fellow panel members. Third, judges may become more efficient the longer they have served, and so the cost of opinion writing may fall. Fourth, experience is - of course - correlated with age. Age, too, may affect self-confidence as well as opinion writing costs (though the direction of these effects is not clear).

Chief Judge Status (C). We control for whether a judge is the chief judge $C$, which allows us to disentangle the effect of presiding from the effect from being chief. As noted above, the chief judge in every circuit always holds the assignment power - at least in its weaker form. One might think that chief judge status negatively affects the propensity to dissent because (a) the chief judge exerts greater influence over other panel members, (b) the chief judge feels a stronger institutional imperative to achieve panel unanimity, and/or (c) the additional responsibilities of the chief judge leave her with less time to draft separate opinions. 
Most Experienced Judge $(M)$. When the chief judge is not on the panel, the presiding judge is the longest-serving judge on the panel in active service. Status as the longest-serving judge on the panel may affect the propensity of dissent for reasons unrelated to the assignment power. For example, the longest-serving judge may command the respect of co-panelists on account of her superior experience. We differentiate the effects of presiding judge status and status as the most experienced judge by including an indicator variable for the most experienced judge on the panel, $M$. Importantly, the most experienced judge on the panel is not necessarily the presiding judge. For example, the most experienced judge might not preside because the chief judge is on the same panel, or the most experienced judge might not preside because she has taken senior status.

Key to our identification strategy is the fact that circuits differ in their rules for allocating the assignment power. Without variation in the assignment power among presiding judges, it would be impossible to isolate the effect of the assignment power from other effects associated with presiding judge status. We use two sources of variation. First, the Fourth Circuit, with its unique rule for opinion assignment, serves as a natural experiment to test the effect of presiding judge status without the concomitant power to assign. When a judge other than the chief judge presides in the Fourth Circuit, we observe the effect of presiding judge status separate from any effect of assignment power $(P=1 ; A=0)$. Second, we exploit variation between circuits that confer a strong form of the assignment power on presiding judges and circuits that give presiding judges a weaker form of the assignment power. ${ }^{12}$

The coefficients $\beta$ and $\theta$ yield the main estimates of interest. $\beta$ relates the assignment power to the probability of dissent. $\theta$ relates the additive effect of the

\footnotetext{
12 In the Fourth Circuit, the chief judge always assigns the panel opinion and so enjoys a strong form of the assignment power in every case that he hears $(P=1 ; A=1 ; S=1 ; C=1)$.
} 
stronger form of the assignment power to the probability of dissent. There are two main identifying assumptions. The first is that there are no other factors that are related to both the assignment power and dissent-aside from presiding judge status, ideological minority status, chief judge status, and absolute and relative experience (all of which we include as controls). We are unaware of any other factor that could plausibly explain the size of the estimated effects below. The second assumption is that, apart from the effect of the assignment power, the effect of presiding judge status on dissent is constant across circuits. ${ }^{13}$

\section{B. Effect of Presiding}

We begin in Table 2 by investigating whether presiding judge status is associated with a lower rate of dissent. As discussed above, this captures both the effect of the assignment power and the other effects of presiding. Column 1 includes year fixed effects. Column 2 adds judge fixed effects. Column 3 adds an indicator for the chief judge and an indicator for the most experienced judge on the panel. In all specifications we control for months of service as a federal appellate judge $(E)$.

\section{Insert Table 2 about here}

Columns 1 to 4 indicate a strong negative relationship between presiding judge status and dissent, and the point estimates in the judge fixed effects models are remarkably consistent after controlling for chief judge status. We find that judges are $17 \%$ less likely to dissent when they preside relative to when they do not preside (0.0019 in Column 4 from a baseline of 0.0114 ). The results also confirm the conventional wisdom that judges vote along party lines. In particular, a judge who is in an ideological minority is roughly $75 \%$ more likely to dissent (point estimate of 0.0088

\footnotetext{
${ }^{13}$ That is, we assume that the effect of presiding judge status in the Fourth Circuit is the same as the effect of presiding judge status in every other circuit except insofar as presiding judge status confers assignment power outside the Fourth Circuit.
} 
relative to the mean of 0.0114 ). The effect of chief judge status is sizeable as well, representing a $12 \%$ lower probability of dissent relative to the judge's lifetime average. Note that each specification controls for differences in the probability of dissenting due to years of experience. Thus, we interpret the point estimate on chief judge status as an effect of the institutional role as chief rather than the effect of experience. This result suggests that studies of the assignment power at the Supreme Court might indeed be contaminated by a "chief justice effect" (i.e., the chief might exert influence through channels other than opinion assignment).

The results in Column 4 allow us to rule out the possibility that the effect of presiding judge status on the probability of dissent is driven by the fact that the presiding judge tends to be the most experienced member of the panel. With the inclusion of a variable that identifies the most experienced member of the panel, the effect of presiding judge status appears to be even more pronounced. Moreover, the effect of being the most experienced panel member on the probability of dissent is positive-contrary to the result we might expect if junior judges on the panel deferred to the preferences of their most senior colleague.

\section{Effect of Assignment Power}

We investigate the extent to which the assignment power rather than status as the presiding judge is driving the lower dissent rate among presiding judges. Table 3 presents the results, which differ from Table 2 in two important ways. First, in each of the columns we include the indicator for whether the presiding judge holds the assignment power, $A$. Second, in Column 4, we include the indicator for whether the presiding judge holds the strong form of the assignment power, $S$.

Consistent with Hypothesis 1, the coefficient on the assignment power in each column is large, negative, and statistically significant. Contrast this with the coefficient on presiding judge status, which is weakly positive in most specifications. Together, the results suggest that the negative effect of presiding judge status on dissent observed in Table 2 is driven through the assignment power. The estimate on the assignment power 
in Column 3 suggests that the judges are 29\% less likely to dissent as a result of the assignment power $(-0.0033$ from a baseline of 0.0114$)$.

The results in Column 4 offer evidence that not only the presence of the assignment power but the strength of the assignment power matters. Part of the large point estimate on the assignment power in Column 3 was driven by the effect of the assignment power in circuits with the strong form (i.e., circuits that allow the presiding judge to assign the panel opinion even when she dissents). With the inclusion of an indicator for the stronger form of the assignment power in Column 4, the main effect on assignment power decreases relative to Column 3 by roughly 11 basis points. The negative coefficient on the indicator for the strong form of the assignment power in Column 4 implies that judges with the stronger form of the assignment power are less likely to dissent than judges with the weaker form of the assignment power. This result is consistent with Hypothesis 2. The coefficients in Column 4 can be interpreted as follows: the ability to assign the panel opinion when in the majority decreases the probability that a judge will dissent by approximately 19\% (-0.0022 from a baseline of 0.0114), while the ability to assign when in dissent decreases that probability by an additional 17\% (-0.0019 from a baseline of 0.0014). This is the opposite of what might be expected if presiding judges were less likely to dissent so that they can assign the majority opinion. The results in Column 4 strongly suggest that the effect observed in the previous section is not the result of presiding judges strategically switching their votes in order to assign the majority opinion.

\section{Mechanisms}

Our further analysis focuses on possible pathways that might allow the presiding judge to influence case outcomes via the assignment power.

Strategic Self-Assignment. We first consider whether presiding judges are disproportionately likely to write majority opinions. As noted above, such a finding would be suggestive of strategic self-assignment. We estimate a series of regressions 
similar to that in Equation 1, but where the outcome is an indicator for whether the judge wrote the majority opinion. Recall that many opinions are "per curiam" and that non-home judges are excluded from the sample, which explains why the average judge in the sample writes the majority in only $18 \%$ of cases (where one $33 \%$ if there were no per curium opinions and all judges were home judges).

Table 4 presents the results. Columns 1 and 2 repeat the preferred specifications from Table 3 but for the outcome of majority opinion writing. In Column 1, we find that status as the presiding judge, the chief judge, and the most experienced judge on a panel are associated with a $19 \%, 6 \%$, and $5 \%$ increase in the likelihood that the judge writes the majority opinion, respectively. Conditional on presiding judge status, chief judge status, and relative experience, we find that the assignment power is not associated with a higher probability of writing the majority opinion.

Column 2 adds an indicator for whether a judge enjoys the strong form of the assignment power (i.e., ability to assign the panel opinion from dissent). The results suggest that judges with the strong form of the assignment power are approximately $11 \%$ less likely to write the majority opinion than other judges, controlling for the general effect of presiding judge status and the effect of the weak form of the assignment power (-0.021 compared to a baseline of 0.183$)$.

One possible explanation for this finding is that judges with the strong form of the assignment power have the option of dissenting while simultaneously assigning the majority opinion to the most ideologically sympathetic co-panelist. Judges with a weak form of the assignment power lack this option-and so are more likely to join the majority opinion and self-assign. Recall, though, that in Column 4 of Table 3, we saw that judges with the strong form of the assignment power are even less likely to dissent than judges with the weak form. Thus, even if strategic voting by judges with a weak form of the assignment power occurs in some circumstances, the phenomenon is not so prevalent as to offset the other factors driving a lower dissent rate among judges with strong-form assignment power. 
In Column 3, we consider whether the effect of the assignment power on the probability of writing the panel opinion is larger for judges in the ideological minority. The estimate on the interaction between assignment power and ideological minority status in Column 3 is weakly negative. This finding is inconsistent with Hypothesis 3 and with the story of strategic self-assignment that Hypothesis 3 reflects. In the circumstances that we might expect judges with the assignment power to be more likely to self-assign, they appear to be - if anything-less likely.

All in all, the results in Table 4 provide very little evidence that assigning judges exert control over case outcomes through strategic self-assignment. The assignment power is not associated with a higher rate of majority opinion writing, and we find no indication of a higher rate of self-assignment among judges in the ideological minority. While we cannot rule out the possibility of strategic self-assignment in a subset of cases, we do not find evidence indicating a consistent pattern of strategic self-assignment.

Strategic Assignment to Other Panel Members. Finally, we investigate whether judges with the assignment power exert influence over case outcomes through strategic assignment of majority opinions to other panel members. Specifically, we assess whether judges with the assignment power are less likely than other judges to dissent even when not the majority opinion author. We restrict the sample to votes of judges who did not write the majority opinion, and test whether non-authoring judges with the assignment power are less likely to dissent than other non-authoring judges.

Table 5 presents the results. Columns 1 and 2 repeat the preferred specifications from Table 3 but with the sample restricted to non-authoring judges (i.e., judges other than the writers of majority opinions). Column 1 suggests that non-authoring judges with the assignment power are approximately $29 \%$ less likely to dissent than other nonauthoring judges (-0.0039 against a baseline of 0.0134). This finding is consistent with Hypothesis 4 above. The fact that the assignment power is associated with a lower dissent rate among non-authoring judges suggests that strategic assignment of opinions 
to other panel members drives part of the lower dissent rate among assigning judges overall.

Column 2 adds an indicator for the strong form of the assignment power, and suggests that non-authoring judges with the strong form of the assignment power are less likely to dissent than non-authoring judges with the weaker form of the assignment power. The strong form of the assignment power is associated with a 19\% reduction in the rate of dissent among non-authoring judges (-0.0026 from a baseline of 0.0134$)$. This

result is consistent with Hypothesis 5. A judge with the stronger form of the assignment power has the ability to control case assignments in a larger set of cases, and so we might expect such a judge to exert greater influence over co-panelists than a judge with a weaker form of the assignment power can.

In Column 3, we consider whether the effect of the assignment power on the dissent rate of non-authoring judges is stronger for non-authoring judges in the ideological minority. The estimate on the interaction between assignment power and ideological minority status is negative, but with a relatively large standard error. We interpret this as suggestive but not definitive evidence that the effect of the assignment power on the dissent rate of non-authoring judges is strongest in the very cases that we would expect the assignment power to matter most: when the judge with the assignment power is in the ideological minority.

\section{CONCLUSION}

In this article, we investigated whether the assignment power allows judges to wield disproportionate influence over case outcomes. We first found that the presiding judge on a three-judge panel is less likely than other panel members to dissent, which can be interpreted as indicating that the presiding judge is more likely to be satisfied with the outcome reached. We found that this effect is distinguishable from the effect of chief judge status and that it is not explained simply by the fact that the presiding judge is generally the most experienced panel member. 
We next considered whether the effect of presiding judge status on case outcomes is attributable to the assignment power or to other aspects of presiding. We took advantage of a natural experiment made possible by the Fourth Circuit's unique rules regarding opinion assignment. If the assignment power were the source of the presiding judge's influence over case outcomes, then we would not expect presiding judges on the Fourth Circuit (other than the chief judge) to exhibit a lower propensity to dissent. Consistent with that expectation, we found that presiding judges without the assignment power are no less likely to dissent than other panel members. The effect of presiding judge status on dissent appears to be a function of the assignment power and not any other effect of presiding judge status.

We then exploited a further difference in assignment rules across circuits: the fact that presiding judges in five circuits can assign the panel opinion even when in dissent while presiding judges in seven other circuits can assign the panel opinion only when in the majority. We found that the negative effect of the assignment power on dissent probability is greatest for judges who wield a stronger form of the assignment power (i.e., who have the ability to assign the panel opinion from dissent). This finding served to dispel the notion that presiding judges are less likely to dissent so that they can assign the panel opinion.

We then sought to determine whether judges with the assignment power wield influence over case outcomes through strategic self-assignment or strategic assignment of opinions to other panel members. We found little evidence of strategic selfassignment but stronger evidence that assigning judges exert influence over case outcomes through strategic assignment of opinions to other panel members. Judges with the assignment power are more likely than other panel members to join the majority when not the authoring judge, and this effect is greatest for judges with a stronger form of the assignment power.

Overall, our results indicate that certain court of appeals judges can wield disproportionate influence over case outcomes by virtue of their control over opinion assignment. These results suggest that observers of multimember courts should pay 
close attention to the hierarchical relationship among panel members as well as the ideological composition of panels. Our results also suggest that subtle differences in institutional rules across circuits can have important effects on case outcomes. 


\section{REFERENCES}

Administrative Office of the U.S. Courts (2016). Federal Judicial Caseload Statistics 2016 Tables. http:/ / www.uscourts.gov/ federal-judicial-caseload-statistics-2016-tables.

Atkins, B. and J. Green (1976). Consensus on the United States Courts of Appeals: Illusion or Reality? American Journal of Political Science 20 (4), 735-748.

Bandiera, O., A. Prat, R. Sadun, and J. Wulf (2015). Span of Control and Span of Attention. Working Paper.

Black, D. (1948). On the Rationale of Group Decision-making. Journal of Political Economy 56 (1), 23-34.

Black, D. (1958). The Theory of Committees and Elections. Cambridge University Press, London, UK.

Brenner, S. (1984). Issue Specialization as a Variable in Opinion Assignment on the U. S. Supreme Court. Journal of Politics 46 (4), 1217-1225.

Brenner, S. (1993). The Chief Justice's Self Assignment of Majority Opinions in Salient Cases. Social Science Journal 30, 143-150.

Broscheid, A. (2011). Comparing Circuits: Are Some U.S. Courts of Appeals More Liberal or Conservative Than Others. Law and Society Review 45, 171-194.

Chen, D. (2014). Digital humanities: Legal analysis in a big data world. Swiss NSF Grant, http:// p3.snf.ch/project-157680 No. 106014-157680, \$413,000.

Chen, D. L., X. Cui, L. Shang, and J. Zheng (2016). What Matters: Agreement between U.S. Courts of Appeals Judges. Working Paper.

Christina L. Boyd, Lee Epstein, A. D. M. (2010). Untangling the Causal Effects of Sex on Judging. American Journal of Political Science 54 (2), 389-411.

Cross, F. B. (2007). Decision Making in the U.S. Courts of Appeals. Stanford University Press, Stanford, CA.

Edwards, H. (2003). The Effects of Collegiality on Judicial Decision Making. University of Pennsylvania Law Review 151, 1639-90.

Epstein, L., W. Landes, and R. Posner (2011). Why (and When) Judges Dissent: A Theoretical and Empirical Analysis. Journal of Legal Analysis 3, 101-37.

Epstein, L., A. Martin, K. Quinn, and J. Segal (2007). Ideological Drift Among Supreme Court Justices: Who, When, and How Important? Northwestern University Law Review 101 (4), 1483-1542.

Farhang, S., J. P. Kastellec, and G. J. Wawro (2015). The Politics of Opinion Assignment and Authorship on the US Court of Appeals: Evidence from Sexual Harassment Cases. Journal of Legal Studies 44 (S1), S59-S85. 
Fischman, J. (2011). Estimating Preferences of Circuit Judges: A Model of Consensus Voting. Journal of Law and Economics 54 (4), 781-809.

Fischman, J. (2014). Measuring Inconsistency, Indeterminacy, and Error in Adjudication. American Law and Economics Review 16 (1), 40-85.

Fischman, J. (2015). Interpreting Circuit Court Voting Patterns: A Social Interactions Framework. Journal of Law, Economics, and Organization 31 (4), 808-842.

Fortas, A. (1975). Chief Justice Warren: The Enigma of Leadership. Yale Law Journal 84, 405-.

George, T. (1998). Developing a Positive Theory of Decisionmaking on U.S. Courts of Appeals. Ohio State Law Journal 58, 1635-1666.

George, T. and A. Yoon (2008). Chief Judges: The Limits of Attitudinal Theory and Possible Paradox of Managerial Judging. Vanderbilt Law Review 61 (1), 1-61.

Glaeser, E. and C. Sunstein (2009). Extremism and Social Learning. Journal of Legal Analysis 1, 263-324.

Gole, T. and S. Quinn (2016). Pride and Prejudice? Structural Evidence of Social Pressure from a Natural Field Experiment with Committees. Working Paper.

Grunwald, B. (2016). Strategic Publication. Working Paper.

Gryski, G., G. Zuk, and S. Goldman (2013). A Multi-User Data Base on the Attributes of U.S. District Court Judges, 1789-2000. National Science Foundation Grant: SBR9810564 (principal district court award).

Hammond, T., C. Bonneau, and R. Sheehan (2005). Strategic Behavior and Policy Choice on the U.S. Supreme Court. Stanford University Press, Palo Alto, CA.

Hettinger, V., S. Lindquist, and W. Martinek (2007). Judging on a Collegial Court: Influences on Federal Appellate Decision Making. University of Virginia Press, Charlottesville, VA.

Howard, J. W. (2014). Courts of Appeals in the Federal Judicial System: A Study of the Second, Fifth, and District of Columbia Circuits. Princeton University Press, Princeton, NJ.

Kastellec, J. (2007). Panel Composition and Judicial Compliance on the US Courts of Appeals. Journal of Law, Economics and Organization 23, 421-41.

Lax, J. and C. Cameron (2007). Bargaining and Opinion Assignment on the US Supreme Court. Journal of Law, Economics, and Organization 23 (2), 276-302.

Levy, G. (2007a). Decision Making in Committees: Transparency, Reputation, and Voting Rules. American Economic Review 97 (1), 150-168.

Levy, G. (2007b). Decision-Making Procedures for Committees of Careerist Experts. American Economic Review, Papers and Proceedings 97 (2), 306-310. 
Maltzman, F., J. Spriggs, and P. Wahlbeck (2000). Crafting Law on the Supreme Court: The Collegial Game. Cambridge University Press, Cambridge, UK.

Maltzman, F. and P. Wahlbeck (1996). May It Please the Chief? Opinion Assignments in the Rehnquist Court. American Journal of Political Science 40 (2), 421-443.

Martin, A. D., K. M. Quinn, and L. Epstein (2005). The Median Justice on the United States Supreme Court. North Carolina Law Review 83, 1275-1321.

Maveety, N. (2005). The Study of Judicial Behavior and the Discipline of Political Science. In N. Maveety (Ed.), The Pioneers of Judicial Behavior, pp. 1-51. University of Michigan Press, Ann Arbor, MI.

Medina, H. (1961). Some Reflections on the Judicial Function at the Appellate Level. Washington University Law Review 1961, 148-156.

Merrill, T. (2003). The Making of the Second Rehnquist Court: A Preliminary Analysis. St. Louis University Law Journal 47, 569-658.

Nash, J. R. (2014). Expertise and Opinion Assignment on the Courts of Appeals: A Preliminary Investigation. Florida Law Review 66, 1599-1684.

Nye, J. (2004). Soft Power: The Means to Success in World Politics. Public Affairs, New York, NY.

Orley Ashenfelter, Theodore Eisenberg, S. J. S. (1995). Politics and the Judiciary: The Influence of Judicial Background on Case Outcomes. The Journal of Legal Studies 24 (2), 257-281.

Parker, J. (1950). Improving Appellate Methods. New York University Law Review 25, 1-15.

Peresie, J. (2005). Female Judges Matter: Gender and Collegial Decision-Making in the Federal Appellate Courts. Yale Law Journal 114, 1759-1790.

Posner, R. A. (1996). The Federal Courts: Challenge and Reform. Harvard University Press, Cambridge, MA.

Schwartz, E. (1992). Policy, Precedent, and Power: A Positive Theory of Supreme Court Decision-Making. Journal of Law, Economics, and Organization 8 (2), 219-252.

Sean Farhang, G. W. (2004). Institutional Dynamics on the U.S. Court of Appeals: Minority Representation under Panel Decision Making. Journal of Law, Economics, and Organization 20 (2), 299-330.

Segal, J. and H. Spaeth (1993). The Supreme Court and the Attitudinal Model.

Sisk, G., M. Heise, and A. Morriss (1998). Charting the Influences on the Judicial Mind: An Empirical Study of Judicial Reasoning. New York University Law Review 73, 13771500.

Slotnick, E. E. (1978). The Chief Justices and Self-Assignment of Majority Opinions: A Research Note. Western Political Quarterly 31 (2), 219-225. 
Smith, J. L. and E. H. Tiller (2002). The Strategy of Judging: Evidence from Administrative Law. Journal of Legal Studies 31 (1), 61-82.

Songer, D. (1982). Consensual and Nonconsensual Decisions in Unanimous Opinions of the United States Courts of Appeals. American Journal of Political Science 26 (2), 225239.

Spitzer, M. and E. Talley (2013). Left, Right, and Center: Strategic Information Acquisition and Diversity in Judicial Panels. Journal of Law, Economics, and Organization 29 (3), 638-680.

Sunstein, C., D. Schkade, L. M. Ellman, and A. Sawicki (2006). Are Judges Political?: An Empirical Analysis of the Federal Judiciary. Brookings Institution Press, Washington, DC.

Ulmer, S. (1970). The Use of Power on the Supreme Court: The Opinion Assignments of Earl Warren, 1953-1960. Journal of Public Law 30, 49-67. 


\section{Figures}

Figure 1: Cases and Votes Over Time

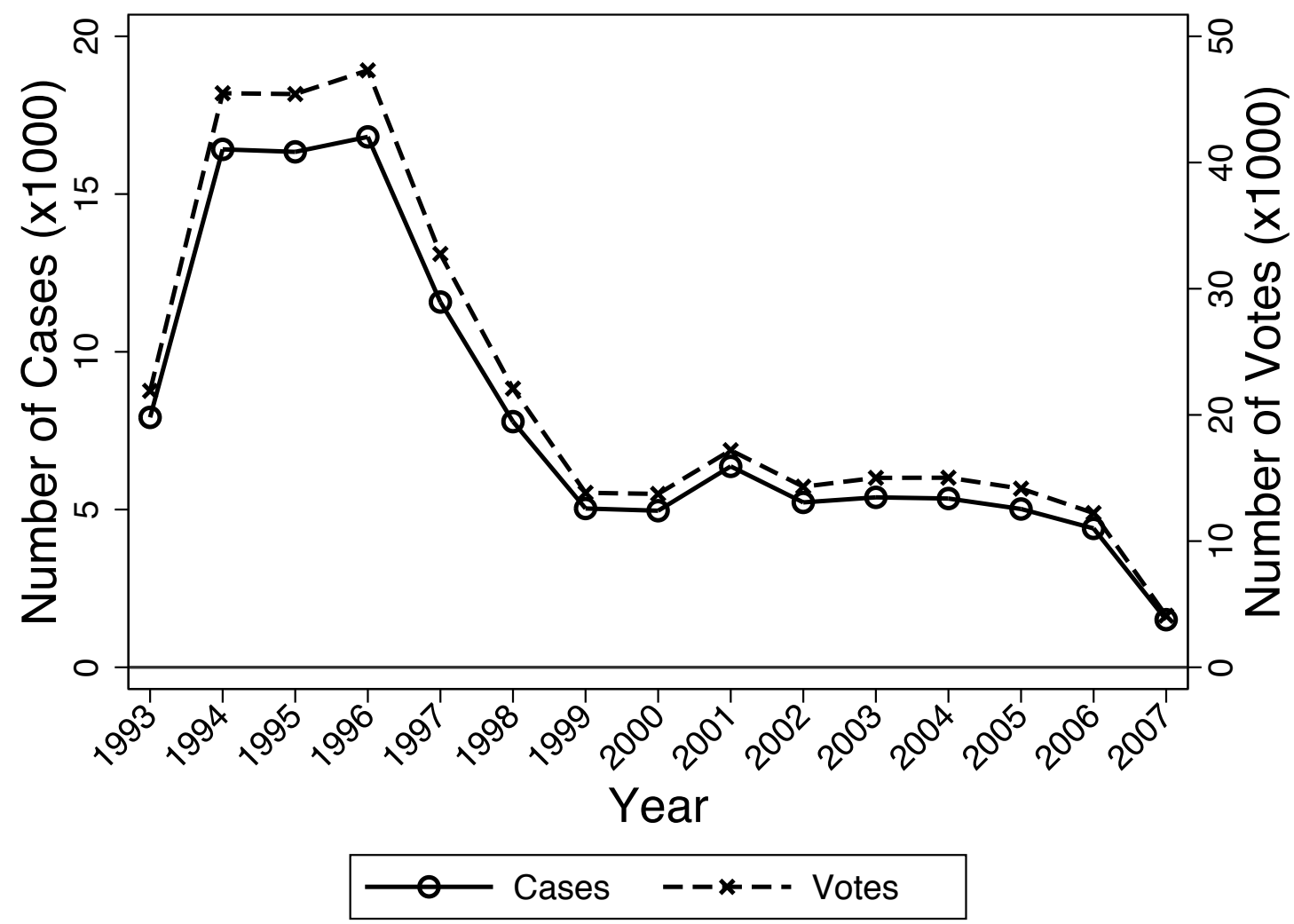


Figure 2: Dissent Rate Over Time

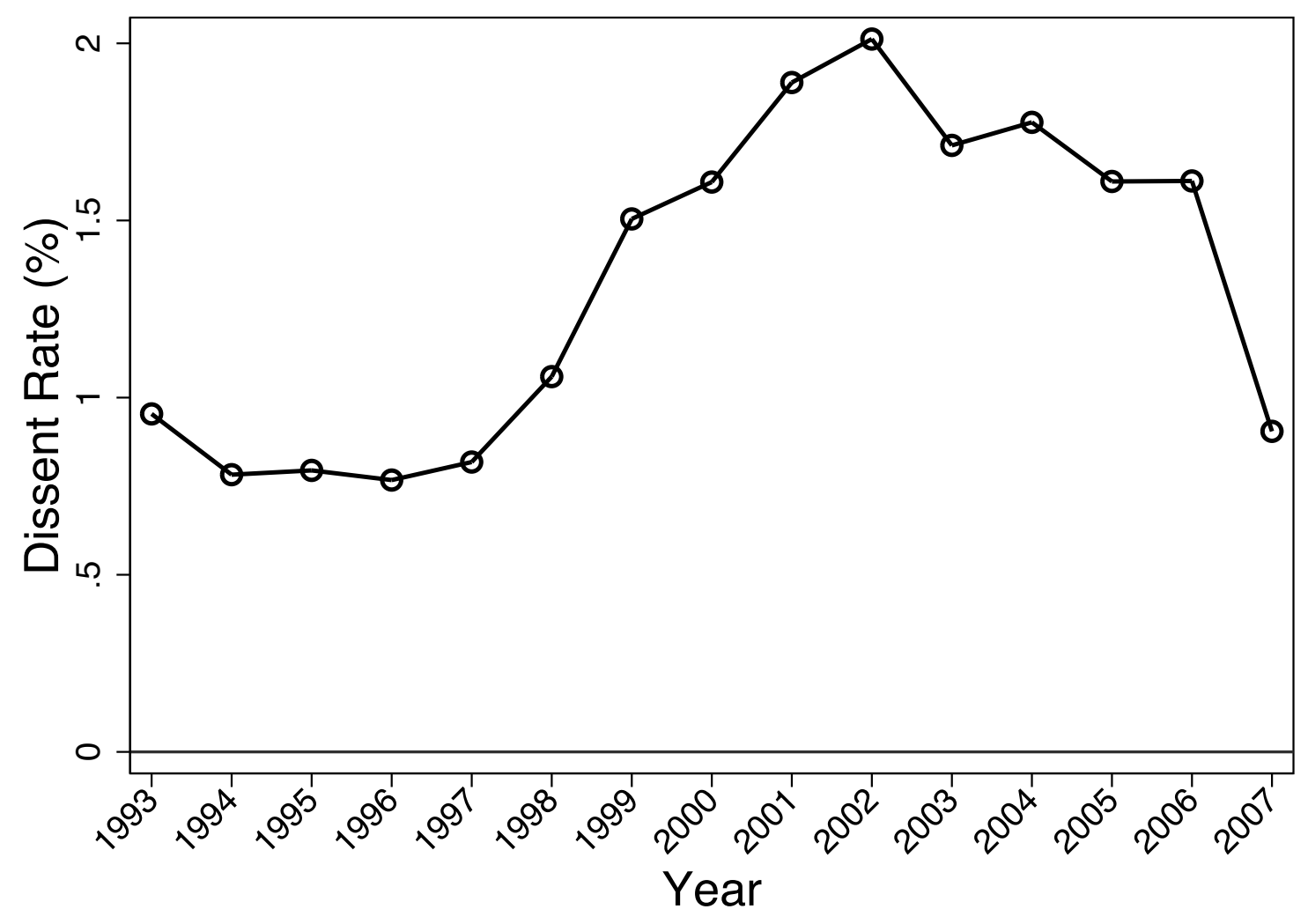


Figure 3: Distribution of Dissent Rate

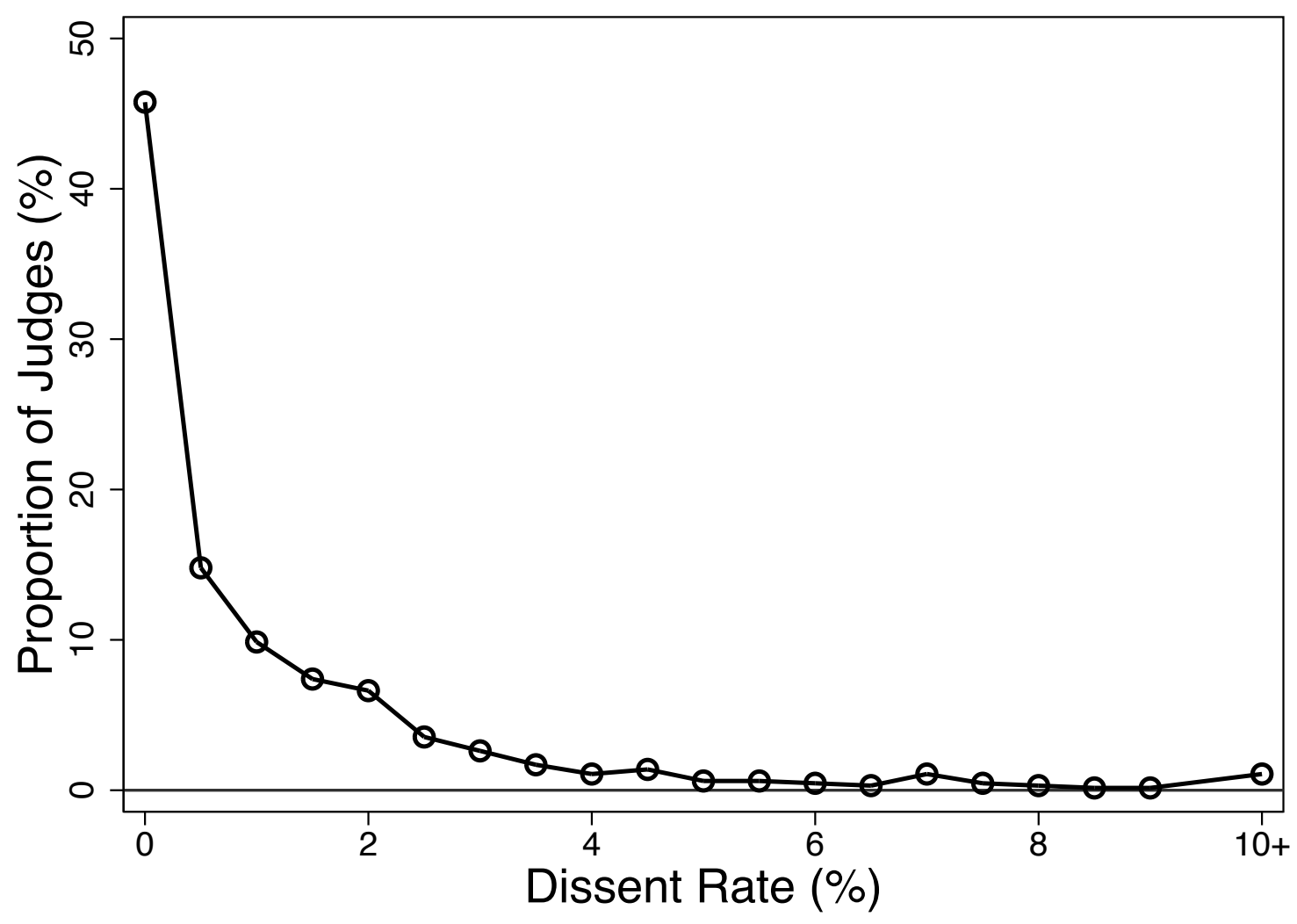




\section{Tables}

Table 1: Descriptive Statistics by Circuit

\begin{tabular}{lcccc}
\hline \hline Circuit & $\begin{array}{c}\text { Home } \\
\text { Judges }\end{array}$ & $\begin{array}{c}\text { Yearly } \\
\text { Cases }\end{array}$ & $\begin{array}{c}\text { Yearly } \\
\text { Votes }\end{array}$ & $\begin{array}{c}\text { Dissent } \\
\text { Rate (\%) }\end{array}$ \\
\hline & & & & \\
1 & 10 & 366 & 998 & 0.3 \\
2 & 20 & 444 & 1138 & 0.8 \\
3 & 18 & 190 & 499 & 3.0 \\
4 & 14 & 856 & 2448 & 2.6 \\
5 & 19 & 438 & 1229 & 0.8 \\
6 & 21 & 728 & 1844 & 1.7 \\
7 & 15 & 797 & 2321 & 0.8 \\
8 & 17 & 842 & 2345 & 1.5 \\
9 & 40 & 1582 & 4314 & 2.0 \\
10 & 17 & 699 & 1878 & 0.8 \\
11 & 17 & 331 & 833 & 1.2 \\
DC & 11 & 257 & 749 & 1.0 \\
FC & 15 & 359 & 1057 & 2.0 \\
& & & & \\
\hline \hline
\end{tabular}


Table 2: Influence of Presiding on Dissent

\begin{tabular}{|c|c|c|c|c|}
\hline & \multicolumn{4}{|c|}{ Dissent } \\
\hline & $(1)$ & $(2)$ & $(3)$ & $(4)$ \\
\hline Preside & $\begin{array}{l}-0.0027^{* * *} \\
(0.0004)\end{array}$ & $\begin{array}{l}{ }^{*}-0.0014^{* * *} \\
(0.0005)\end{array}$ & $\begin{array}{l}-0.0013^{* * *} \\
(0.0005)\end{array}$ & $\begin{array}{l}-0.0019^{* * *} \\
(0.0005)\end{array}$ \\
\hline Ideological Minority on Panel & $\begin{array}{l}0.0087^{* * *} \\
(0.0006)\end{array}$ & $\begin{array}{l}0.0087^{* * *} \\
(0.0006)\end{array}$ & $\begin{array}{l}0.0087^{* * *} \\
(0.0006)\end{array}$ & $\begin{array}{l}0.0088^{* * *} \\
(0.0006)\end{array}$ \\
\hline Chief Judge & & & $\begin{array}{l}-0.0016 \\
(0.0010)\end{array}$ & $\begin{array}{l}-0.0014 \\
(0.0010)\end{array}$ \\
\hline Most Experienced Judge on Panel & & & & $\begin{array}{l}0.0020^{* * *} \\
(0.0005)\end{array}$ \\
\hline Covariates & & & & \\
\hline Judge FE & No & Yes & Yes & Yes \\
\hline Year FE & Yes & Yes & Yes & Yes \\
\hline Experience & Yes & Yes & Yes & Yes \\
\hline $\mathrm{N}$ & 334,551 & 334,551 & 334,551 & 334,551 \\
\hline Dep Var Mean & 0.0114 & 0.0114 & 0.0114 & 0.0114 \\
\hline
\end{tabular}


Table 3: Influence of the Assignment Power on Dissent

\begin{tabular}{|c|c|c|c|c|}
\hline & \multicolumn{4}{|c|}{ Dissent } \\
\hline & (1) & $(2)$ & $(3)$ & (4) \\
\hline Assignment Power & $\begin{array}{l}-0.0029^{* * *} \\
(0.0010)\end{array}$ & $\begin{array}{l}{ }^{*}-0.0040^{* * *} \\
(0.0015)\end{array}$ & $\begin{array}{l}-0.0033^{* *} \\
(0.0015)\end{array}$ & $\begin{array}{l}-0.0022 \\
(0.0016)\end{array}$ \\
\hline Preside & $\begin{array}{c}-0.0001 \\
(0.0010)\end{array}$ & $\begin{array}{c}0.0022 \\
(0.0015)\end{array}$ & $\begin{array}{c}0.0012 \\
(0.0015)\end{array}$ & $\begin{array}{c}0.0012 \\
(0.0015)\end{array}$ \\
\hline Ideological Minority on Panel & $\begin{array}{l}0.0087^{* * *} \\
(0.0006)\end{array}$ & $\begin{array}{l}0.0087^{* * *} \\
(0.0006)\end{array}$ & $\begin{array}{l}0.0088^{* * *} \\
(0.0006)\end{array}$ & $\begin{array}{c}0.0088^{* * *} \\
(0.0006)\end{array}$ \\
\hline Chief Judge & & & $\begin{array}{l}-0.0011 \\
(0.0010)\end{array}$ & $\begin{array}{c}-0.0013 \\
(0.0010)\end{array}$ \\
\hline Most Experienced Judge on Panel & & & $\begin{array}{l}0.0019^{* * *} \\
(0.0005)\end{array}$ & $\begin{array}{c}0.0019^{* * *} \\
(0.0005)\end{array}$ \\
\hline Strong-Form Assignment Power & & & & $\begin{array}{l}-0.0019^{* *} \\
(0.0010)\end{array}$ \\
\hline \multicolumn{5}{|l|}{ Covariates } \\
\hline Judge FE & No & Yes & Yes & Yes \\
\hline Year FE & Yes & Yes & Yes & Yes \\
\hline Experience & Yes & Yes & Yes & Yes \\
\hline $\mathrm{N}$ & 334,551 & 334.551 & 334,551 & 334,551 \\
\hline Dep Var Mean & 0.0114 & 0.0114 & 0.0114 & 0.0114 \\
\hline $\begin{array}{l}\text { Note: Standard errors in parentheses. } \\
\text { clustered by case. Presiding judges other } \\
\text { power in the Fourth Circuit. In the First, } \\
\text { Circuits, the next ranking judge in the ma } \\
\text { judge dissents. In the Fifth, Sixth, Sevent } \\
\text { assigns the majority opinion even when s }\end{array}$ & $\begin{array}{l}\mathrm{p}<0.1,{ }^{* *} \mathrm{p} \\
\text { than the chi } \\
\text { Decond, Thirc } \\
\text { jority assigns } \\
\text { h, Eighth, an } \\
\text { he dissents (' }\end{array}$ & $\begin{array}{l}<0.05,{ }^{* * *} \mathrm{p} \\
\text { ef judge do } 1 \\
\text { d, Tenth, Ele } \\
\text { the panel op } \\
\text { d Ninth Circ } \\
\text { "Strong-Form }\end{array}$ & $\begin{array}{l}<0.01 \text {. Stan } \\
\text { not hold the } \\
\text { venth, D.C., } \\
\text { inion when tl } \\
\text { uits, the pres } \\
\text { Assignment }\end{array}$ & $\begin{array}{l}\text { dard errors } \\
\text { assignment } \\
\text { and Federal } \\
\text { he presiding } \\
\text { iding judge } \\
\text { Power"). }\end{array}$ \\
\hline
\end{tabular}


Table 4: Assignment of Opinion Writing

\begin{tabular}{|c|c|c|c|}
\hline & \multicolumn{3}{|c|}{ "Wrote Majority Opinion } \\
\hline & (1) & $(2)$ & $(3)$ \\
\hline Assignment Power & $\begin{array}{l}-0.006 \\
(0.005)\end{array}$ & $\begin{array}{c}0.007 \\
(0.005)\end{array}$ & $\begin{array}{c}0.007 \\
(0.005)\end{array}$ \\
\hline Preside & $\begin{array}{l}0.034^{* * *} \\
(0.004)\end{array}$ & $\begin{array}{l}0.035^{* * *} \\
(0.004)\end{array}$ & $\begin{array}{l}0.035^{* * *} \\
(0.004)\end{array}$ \\
\hline Ideological Minority on Panel & $\begin{array}{l}-0.016^{* * *} \\
(0.002)\end{array}$ & $\begin{array}{l}-0.016^{* * *} \\
(0.002)\end{array}$ & $\begin{array}{l}-0.015^{* * *} \\
(0.002)\end{array}$ \\
\hline Chief Judge & $\begin{array}{l}0.011^{* *} \\
(0.004)\end{array}$ & $\begin{array}{l}0.009^{* *} \\
(0.004)\end{array}$ & $\begin{array}{l}0.009^{* *} \\
(0.004)\end{array}$ \\
\hline Most Experienced Judge on Panel & $\begin{array}{l}0.009^{* * *} \\
(0.002)\end{array}$ & $\begin{array}{l}0.009^{* * *} \\
(0.002)\end{array}$ & $\begin{array}{l}0.009^{* * *} \\
(0.002)\end{array}$ \\
\hline Strong-Form Assignment Power & & $\begin{array}{l}-0.021^{* * *} \\
(0.004)\end{array}$ & $\begin{array}{l}-0.021^{* * *} \\
(0.004)\end{array}$ \\
\hline $\begin{array}{l}\text { Assignment Power } \\
\times \text { Ideological Minority on Panel }\end{array}$ & & & $\begin{array}{l}-0.004 \\
(0.004)\end{array}$ \\
\hline Covariates & & & \\
\hline $\begin{array}{l}\text { Judge FE } \\
\text { Year FE } \\
\text { Experience }\end{array}$ & $\begin{array}{l}\text { Yes } \\
\text { Yes } \\
\text { Yes }\end{array}$ & $\begin{array}{l}\text { Yes } \\
\text { Yes } \\
\text { Yes }\end{array}$ & $\begin{array}{l}\text { Yes } \\
\text { Yes } \\
\text { Yes }\end{array}$ \\
\hline $\begin{array}{l}\text { N } \\
\text { Dep Var Mean }\end{array}$ & $\begin{array}{c}334,551 \\
0.183\end{array}$ & $\begin{array}{c}334,551 \\
0.183\end{array}$ & $\begin{array}{c}334,551 \\
0.183\end{array}$ \\
\hline $\begin{array}{l}\text { Note: Standard errors in parentheses. }{ }^{*} \mathrm{p} \\
\text { dard errors clustered by case. Presiding } \\
\text { not hold the assignment power in the Fo } \\
\text { Third, Tenth, Eleventh, D.C., and Federa } \\
\text { the majority assigns the panel opinion wh } \\
\text { the Fifth, Sixth, Seventh, Eighth, and Nir } \\
\text { signs the majority opinion even when she } \\
\text { Power"). }\end{array}$ & $\begin{array}{l}<0.1,{ }^{* *} \mathrm{p}<0 \\
\text { dges other t } \\
\text { irth Circuit. } \\
\text { Circuits, the } \\
\text { en the presic } \\
\text { th Circuits, } \\
\text { lissents ("Str }\end{array}$ & $\begin{array}{l}.05,{ }^{* * *} \mathrm{p}<0 \\
\text { han the chie } \\
\text { In the Firs } \\
\text { e next rankin } \\
\text { ding judge di } \\
\text { the presiding } \\
\text { rong-Form A }\end{array}$ & $\begin{array}{l}\text {.01. Stan- } \\
\text { judge do } \\
\text { t, Second, } \\
\text { ig judge in } \\
\text { issents. In } \\
\text { judge as- } \\
\text { ssignment }\end{array}$ \\
\hline
\end{tabular}


Table 5: Mechanisms: Influence of Assignment Power on Dissent for Non-Majority Writer

\begin{tabular}{|c|c|c|c|}
\hline & \multicolumn{3}{|c|}{ Dissent } \\
\hline & $(1)$ & $(2)$ & $(3)$ \\
\hline Assignment Power & $\begin{array}{l}-0.0039^{* *} \\
(0.0017)\end{array}$ & $\begin{array}{c}-0.0024 \\
(0.0019)\end{array}$ & $\begin{array}{l}-0.0021 \\
(0.0019)\end{array}$ \\
\hline Preside & $\begin{array}{c}0.0018 \\
(0.0017)\end{array}$ & $\begin{array}{c}0.0019 \\
(0.0017)\end{array}$ & $\begin{array}{c}0.0019 \\
(0.0017)\end{array}$ \\
\hline Ideological Minority on Panel & $\begin{array}{l}0.0100^{* * *} \\
(0.0007)\end{array}$ & $\begin{array}{l}0.0100^{* * *} \\
(0.0007)\end{array}$ & $\begin{array}{l}0.0106^{* * *} \\
(0.0009)\end{array}$ \\
\hline Chief Judge & $\begin{array}{l}-0.0013 \\
(0.0013)\end{array}$ & $\begin{array}{l}-0.0016 \\
(0.0014)\end{array}$ & $\begin{array}{l}-0.0015 \\
(0.0014)\end{array}$ \\
\hline Most Experienced Judge on Panel & $\begin{array}{l}0.0028^{* * *} \\
(0.0006)\end{array}$ & $\begin{array}{l}0.0028^{* * *} \\
(0.0006)\end{array}$ & $\begin{array}{l}0.0028^{* * *} \\
(0.0006)\end{array}$ \\
\hline Strong-Form Assignment Power & & $\begin{array}{l}-0.0026^{* *} \\
(0.0012)\end{array}$ & $\begin{array}{l}-0.0026^{* *} \\
(0.0012)\end{array}$ \\
\hline $\begin{array}{l}\text { Assignment Power } \\
\times \text { Ideological Minority on Panel }\end{array}$ & & & $\begin{array}{l}-0.0018 \\
(0.0015)\end{array}$ \\
\hline \multicolumn{4}{|l|}{ Covariates } \\
\hline Judge FE & Yes & Yes & Yes \\
\hline Year FE & Yes & Yes & Yes \\
\hline Experience & Yes & Yes & Yes \\
\hline $\mathrm{N}$ & 271,373 & 271,373 & 271,373 \\
\hline Dep Var Mean & 0.0134 & 0.0134 & 0.0134 \\
\hline \multicolumn{4}{|c|}{$\begin{array}{l}\text { Note: Standard errors in parentheses. }{ }^{*} \mathrm{p}<0.1,{ }^{* *} \mathrm{p}<0.05,{ }^{* * *} \mathrm{p}<0.01 \text {. Stan- } \\
\text { dard errors clustered by case. The sample is restricted to judge-votes of judges } \\
\text { who do not write the majority opinion. Presiding judges other than the chief } \\
\text { judge do not hold the assignment power in the Fourth Circuit. In the First, } \\
\text { Second, Third, Tenth, Eleventh, D.C., and Federal Circuits, the next rank- } \\
\text { ing judge in the majority assigns the panel opinion when the presiding judge } \\
\text { dissents. In the Fifth, Sixth, Seventh, Eighth, and Ninth Circuits, the presid- } \\
\text { ing judge assigns the majority opinion even when she dissents ("Strong-Form } \\
\text { Assignment Power"). }\end{array}$} \\
\hline
\end{tabular}




\section{Appendix}

Table A1: Influence of Presiding on Disagreement (Dissent or Concur)

\begin{tabular}{|c|c|c|c|c|}
\hline & \multicolumn{4}{|c|}{ Dissent or Concur } \\
\hline & $(1)$ & $(2)$ & $(3)$ & $(4)$ \\
\hline Preside & $\begin{array}{l}-0.0038^{* * *} \\
(0.0005)\end{array}$ & $\begin{array}{l}{ }^{*}-0.0017^{* * *} \\
(0.0006)\end{array}$ & $\begin{array}{l}{ }^{*}-0.0015^{* *} \\
(0.0006)\end{array}$ & $\begin{array}{l}-0.0023^{* * *} \\
(0.0006)\end{array}$ \\
\hline Ideological Minority on Panel & $\begin{array}{l}0.0112^{* * *} \\
(0.0007)\end{array}$ & $\begin{array}{l}0.0113^{* * *} \\
(0.0008)\end{array}$ & $\begin{array}{l}0.0113^{* * *} \\
(0.0008)\end{array}$ & $\begin{array}{c}0.0114^{* * *} \\
(0.0008)\end{array}$ \\
\hline Chief Judge & & & $\begin{array}{l}-0.0025^{* *} \\
(0.0012)\end{array}$ & $\begin{array}{l}-0.0022^{*} \\
(0.0012)\end{array}$ \\
\hline Most Experienced Judge on Panel & & & & $\begin{array}{l}0.0029^{* * *} \\
(0.0006)\end{array}$ \\
\hline Covariates & & & & \\
\hline Judge FE & No & Yes & Yes & Yes \\
\hline Year FE & Yes & Yes & Yes & Yes \\
\hline Experience & Yes & Yes & Yes & Yes \\
\hline $\mathrm{N}$ & 334,551 & 334,551 & 334,551 & 334,551 \\
\hline Dep Var Mean & 0.0182 & 0.0182 & 0.0182 & 0.0182 \\
\hline
\end{tabular}


Table A2: Influence of the Assignment Power on Disagreement (Dissent or Concur)

\begin{tabular}{|c|c|c|c|c|}
\hline & \multicolumn{4}{|c|}{ Dissent or Concurrence } \\
\hline & (1) & $(2)$ & (3) & (4) \\
\hline Assignment Power & $\begin{array}{l}-0.0030^{* *} \\
(0.0012)\end{array}$ & $\begin{array}{l}-0.0056^{* * *} \\
(0.0017)\end{array}$ & $\begin{array}{c}{ }^{*}-0.0046^{* * *} \\
(0.0017)\end{array}$ & $\begin{array}{l}-0.0023 \\
(0.0019)\end{array}$ \\
\hline Preside & $\begin{array}{l}-0.0010 \\
(0.0012)\end{array}$ & $\begin{array}{c}0.0034^{* *} \\
(0.0016)\end{array}$ & $\begin{array}{c}0.0019 \\
(0.0017)\end{array}$ & $\begin{array}{c}0.0021 \\
(0.0017)\end{array}$ \\
\hline Ideological Minority on Panel & $\begin{array}{l}0.0112^{* * *} \\
(0.0007)\end{array}$ & $\begin{array}{l}0.0113^{* * *} \\
(0.0008)\end{array}$ & $\begin{array}{l}0.0114^{* * *} \\
(0.0008)\end{array}$ & $\begin{array}{l}0.0114^{* * *} \\
(0.0008)\end{array}$ \\
\hline Chief Judge & & & $\begin{array}{l}-0.0018 \\
(0.0012)\end{array}$ & $\begin{array}{l}-0.0021^{*} \\
(0.0012)\end{array}$ \\
\hline Most Experienced Judge on Panel & & & $\begin{array}{l}0.0027^{* * *} \\
(0.0006)\end{array}$ & $\begin{array}{l}0.0027^{* * *} \\
(0.0006)\end{array}$ \\
\hline Strong-Form Assignment Power & & & & $\begin{array}{l}-0.0039^{* * *} \\
(0.0012)\end{array}$ \\
\hline Covariates & & & & \\
\hline Judge FE & No & Yes & Yes & Yes \\
\hline Year FE & Yes & Yes & Yes & Yes \\
\hline Experience & Yes & Yes & Yes & Yes \\
\hline $\mathrm{N}$ & 334,551 & 334,551 & 334,551 & 334,551 \\
\hline Dep Var Mean & 0.0182 & 0.0182 & 0.0182 & 0.0182 \\
\hline $\begin{array}{l}\text { Note: Standard errors in parentheses. } \\
\text { clustered by case. Presiding judges othe } \\
\text { power in the Fourth Circuit. In the First } \\
\text { Circuits, the next ranking judge in the m } \\
\text { judge dissents. In the Fifth, Sixth, Seven } \\
\text { assigns the majority opinion even when }\end{array}$ & $\begin{array}{l}<0.1,{ }^{* *} \mathrm{p} \\
\text { han the chi } \\
\text { cond, Third } \\
\text { rity assigns } \\
\text { Eighth, anc } \\
\text { dissents (" }\end{array}$ & $\begin{array}{l}<0.05,{ }^{* * *} \mathrm{p}< \\
\text { ef judge do } \mathrm{n} \\
\text { l, Tenth, Elev } \\
\text { the panel opir } \\
\text { d Ninth Circu } \\
\text { Strong-Form }\end{array}$ & $\begin{array}{l}<0.01 . \text { Stand } \\
\text { not hold the a } \\
\text { venth, D.C., a } \\
\text { inion when the } \\
\text { uits, the presi } \\
\text { Assignment }\end{array}$ & $\begin{array}{l}\text { dard errors } \\
\text { assignment } \\
\text { and Federal } \\
\text { le presiding } \\
\text { iding judge } \\
\text { Power"). } \\
\end{array}$ \\
\hline
\end{tabular}


Table A3: Mechanisms: Influence of Presiding on Disagreement (Dissent or Concur) for Non-Majority Writer

\begin{tabular}{|c|c|c|c|}
\hline & \multicolumn{3}{|c|}{ Dissent or Concur } \\
\hline & $(1)$ & $(2)$ & $(3)$ \\
\hline Assignment Power & $\begin{array}{l}-0.0052^{* * *} \\
(0.0020)\end{array}$ & $\begin{array}{l}-0.0024 \\
(0.0022)\end{array}$ & $\begin{array}{l}-0.0023 \\
(0.0022)\end{array}$ \\
\hline Preside & $\begin{array}{c}0.0025 \\
(0.0018)\end{array}$ & $\begin{array}{c}0.0026 \\
(0.0018)\end{array}$ & $\begin{array}{c}0.0026 \\
(0.0018)\end{array}$ \\
\hline Ideological Minority on Panel & $\begin{array}{l}0.0130^{* * *} \\
(0.0009)\end{array}$ & $\begin{array}{l}0.0130^{* * *} \\
(0.0009)\end{array}$ & $\begin{array}{l}0.0133^{* * *} \\
(0.0011)\end{array}$ \\
\hline Chief Judge & $\begin{array}{l}-0.0021 \\
(0.0017)\end{array}$ & $\begin{array}{l}-0.0026 \\
(0.0017)\end{array}$ & $\begin{array}{l}-0.0026 \\
(0.0017)\end{array}$ \\
\hline Most Experienced Judge on Panel & $\begin{array}{l}0.0038^{* * *} \\
(0.0008)\end{array}$ & $\begin{array}{l}0.0038^{* * *} \\
(0.0008)\end{array}$ & $\begin{array}{l}0.0038^{* * *} \\
(0.0008)\end{array}$ \\
\hline Strong-Form Assignment Power & & $\begin{array}{l}-0.0046^{* * *} \\
(0.0015)\end{array}$ & $\begin{array}{l}-0.0046^{* * *} \\
(0.0015)\end{array}$ \\
\hline $\begin{array}{l}\text { Assignment Power } \\
\times \text { Ideological Minority on Panel }\end{array}$ & & & $\begin{array}{l}-0.0008 \\
(0.0018)\end{array}$ \\
\hline \multicolumn{4}{|l|}{ Covariates } \\
\hline $\begin{array}{l}\text { Judge FE } \\
\text { Year FE } \\
\text { Experience }\end{array}$ & $\begin{array}{l}\text { Yes } \\
\text { Yes } \\
\text { Yes }\end{array}$ & $\begin{array}{l}\text { Yes } \\
\text { Yes } \\
\text { Yes }\end{array}$ & $\begin{array}{l}\text { Yes } \\
\text { Yes } \\
\text { Yes }\end{array}$ \\
\hline $\begin{array}{l}\mathrm{N} \\
\text { Dep Var Mean }\end{array}$ & $\begin{array}{c}271,373 \\
0.0211\end{array}$ & $\begin{array}{c}271,373 \\
0.0211\end{array}$ & $\begin{array}{c}271,373 \\
0.0211\end{array}$ \\
\hline \multicolumn{4}{|c|}{$\begin{array}{l}\text { Note: Standard errors in parentheses. }{ }^{*} \mathrm{p}<0.1,{ }^{* *} \mathrm{p}<0.05,{ }^{* * *} \mathrm{p}<0.01 \text {. Standard } \\
\text { errors clustered by case. The sample is restricted to judge-votes of judges who } \\
\text { do not write the majority opinion. Presiding judges other than the chief judge } \\
\text { do not hold the assignment power in the Fourth Circuit. In the First, Second, } \\
\text { Third, Tenth, Eleventh, D.C., and Federal Circuits, the next ranking judge in } \\
\text { the majority assigns the panel opinion when the presiding judge dissents. In the } \\
\text { Fifth, Sixth, Seventh, Eighth, and Ninth Circuits, the presiding judge assigns the } \\
\text { majority opinion even when she dissents ("Strong-Form Assignment Power"). }\end{array}$} \\
\hline
\end{tabular}

